\title{
Perceived Risk on Online Store Image Towards Purchase Intention
}

\author{
Lu Man Hong ${ }^{1}$, Noorshella Che Nawi ${ }^{1}$, Wan Farha Wan Zulkiffli ${ }^{1}$, Dzulkifli Mukhtar ${ }^{1} \&$ Shah Iskandar Fahmie \\ Ramlee $^{1}$ \\ ${ }^{1}$ Faculty of Entrepreneurship and Business, Universiti Malaysia Kelantan, Malaysia \\ Correspondence: Lu Man Hong, Faculty of Entrepreneurship and Business, Universiti Malaysia Kelantan, Malaysia.
}

Received: May 1, 2019

doi:10.5430/rwe.v10n2p48
Accepted: June 1, 2019

Online Published: July 7, 2019

URL: https://doi.org/10.5430/rwe.v10n2p48

\begin{abstract}
The main aim of this study is to identify purchase intention among Malaysian online consumer towards online store. A recent data provided by MCMC indicate that only 9.3 percent of Internet users in Malaysia admitted doing online purchasing despite huge number reflects Malaysian is heavy Internet users. This is due to the factors that the consumers are feared towards risk they may get during shopping online and this can affect their purchase intention activities. The finding identified that privacy risk and delivery risk are significant to purchase intention among online consumers in Malaysia. Meanwhile, financial risk, product performance risk, time risk, psychological risk, social risk and after-sale risk are not significant to purchase intention. This indicated that Malaysian online consumers tend to care their personal information has been misused by third parties within their permission in order to prevent privacy risk in online shopping activities.
\end{abstract}

Keywords: online consumer, perceived risks, purchase intention

\section{Introduction}

E-commerce is a business activity that involves a product, services and information transfer (Lu, Zulkiffli, \& Hamsani, 2016). Lu et al. (2016) added E-commerce bring many conveniences among social that includes no barriers for time and place that results in individuals able to make purchasing on the world stage. Tanadi, Samadi, and Gharleghi (2015) showed a data revealed that only 9.3 percent of Malaysian Internet user doing online purchasing although Malaysian is heavy Internet users. Therefore, this reflects Malaysian online consumers have the low intention to shops online due to certain issues like perceived risk and this is supported the finding from Ariff et al. (2014), Dhanapal et al. (2015) and Chen and Teng (2013). There are many types of risks involved in online purchase. Ariff et al. (2014) ranked financial risk as the first rank due to consumers trying to avoid financial loss when online shopping (Javadi et al., 2012; Tanadi et al., 2015). Furthermore, Tanadi et al. (2015) and Javadi et al. (2012) stated that online consumers in Malaysia think that the actual products might not similar as product description which results in product performance risk as second place (Ariff et al., 2014). Time is one of the risks that consider by Malaysian online consumers (Ariff et al., 2014; Javadi et al., 2012; Tanadi et al., 2015) because they found that time waste for return malfunction product to sellers and includes delivery process. Moreover, the result of delivery process results in the intention of online consumers in Malaysia to shops online (Javadi et al., 2012; Tanadi et al., 2015) which makes delivery risk ranked at fourth (Ariff et al., 2014; Rahman \& Zhang 2017). Besides that, personal information that provided from consumers was used by online retailers without permission results privacy risk in fifth place (Tanadi et al., 2015). Low product performance will result in online consumers' self-image been affected in Malaysia by the review from Lu et al. (2016) who identify psychological risk ranked at sixth. Finally, the last place will be a social risk due to online consumers in Malaysia try to prevent them be angry and shame by family members and friends about wrong decision making (Morad \& Raman, 2015). Although after-sale risk was not ranked, the researcher considers this risk can be influence consumers' purchase intention when shops online as a study from Zhang, Tan, Xu, and Tan (2012) defined that online consumers in China are important for claiming after-sale service such as money-guarantee back from online retailers when making purchasing. Therefore, this study is intended to examine the perceived risk that may arise during online shopping that thus may affect online purchasing behavior among Malaysian consumers. 


\section{Literature Review}

Meanwhile, Juniwati (2014) believed that behavior intention is evaluation of person towards a certain product or services. Recent study by Pappas (2016) comprised that online retailers should aware the importance of consumers' purchase intention due to intention defined as the last steps in buying behavior process. Hence, purchase intention in this study is defined as the outcome for consumers might react to get, use and dispose of products or services in some ways. Perceived risk is not a new issue in marketing literature (Bauer 1960). Javadi et al. (2012) stated that consumers willing to make purchasing based on the perceived risk that will consumers face. Hence in this study, perceived risks conclude as consumers feel scared or bad for the negative results and an unfavourable outcome in online shopping activities (Ariff et al., 2014; Lu et al., 2016; Tanadi et al., 2015; Raza,et.al 2017). Kumar and Bajaj (2016) stated that consumers concern with credit card transaction and extra charge on delivery. Moreover, Ariff et al. (2014) state that Malaysian online shoppers really take seriously on financial risk to avoid financial loss. Another risk that consumer may face during purchase online is product performance risk. Based on Kumar and Bajaj (2016) product performance risk can be identified by product quality, the function of the product, problem happen for that product and product performance can meet expectation. Indeed, this risk can occur among consumers due to the product is do not meet their expectation (Ariff et al., 2014). Asawa and Kumar (2016) stated that consumer considers time as one of the risk. In other words, the customers do not want to waste their time for making a bad decision towards products or services. According to Thakur and Srivastava (2015), consumers afraid to shop online due to their personal information will be misused by other third parties. Zhang et al. (2012) also shared the same finding that consumers concern about their information such as contact number, email address and many confidential information been disclosure by online retailers to other parties. Taking this into account, privacy risk in this study defined as the probability for consumers feels angry due to online retailers use their personal information without permission and proper ways. According to Kumar and Bajaj (2016) stated that consumers may feel sad due to product purchasing from online. While Zheng et al. (2012) stated that consumers feel frustration because of the product purchased does not meet expectation which caused their self-esteem been loss. In result, the definition of psychological risk in this study as a possibility for consumers scares self-image and self-concept will be lost and the products may not suit for their image due to the product purchased (Asawa \& Kumar, 2016; Riaz \& Riaz 2018). Social risk can happen when individuals scare the product purchased may result in blameful ness from friends (Asawa \& Kumar, 2016; Zheng et al., 2012; Singh, 2018). Therefore, the social risk is defined as the probability of consumer loss their identity and status among social group due to decision making for products or services (Zheng et al., 2012). Another factor that customers fear to shop online is delivery as stated by Tanadi et al. (2015). Tanadi et al., (2015) further added that customers want their product been arrived timely has been promised by the seller and receive the product in good condition. Taking this into consideration, delivery risk in this study is defined as the probability for consumers to concern about the result of the delivery process (Zhang et al., 2012). Consumers feel important towards after-sale services to include warranty, guarantee, malfunction product returning and more even in traditional stores and online stores (Zhang et al., 2012; Singh, Hussein \& Dahlan 2018). Therefore, after-sale risk in this study is defined as the probability for consumer's concern toward risk issues after they received the product (Zhang et al., 2012).

H1: Perceived financial risk will negatively influence online purchase intention.

$\mathrm{H} 2$ : Perceived product performance risk will negatively influence online purchase intention.

H3: Perceived time risk will negatively influence online purchase intention.

H4: Perceived privacy risk will negatively influence online purchase intention.

H5: Perceived psychological risk will negatively influence online purchase intention.

H6: Perceived social risk will negatively influence online purchase intention.

H7: Perceived delivery risk will negatively influence online purchase intention.

H8: Perceived after-sale risk will negatively influence online purchase intention.

\section{Methodology}

This study employed quantitative research. The population for this study is consumer who has experienced purchase online. There are 31.8 million Internet users in Malaysia. Apart from that, who has experienced purchased online. Hence, using G Power Tool, the sample for this study is 200 . Online questionnaire was distributed to the respondents using Google form. The data then been analaysed using descriptive analysis and the hypotheses been tested using Smart PLS. 


\section{Result and Finding}

\subsection{Descriptive Analysis for Demographic Profile}

It can summary that female is dominant gender in online shopping activities in this study with Chinese online shoppers are the most active to shop online compare to other races. In the terms of age, individuals who year age 18 to 26 are most active buyers in online following up by individuals with age 27 to 35 and 46 to 52 respectively. Moreover, the researchers identify mostly Malaysian online shoppers educated to the level of a Bachelor's degree in order to dominate online shopping activities following up by STPM level. Lastly, researchers identify students even in part time or full time are the most active online buyers in this study.

\subsection{The Measurement Model Analysis}

The result of measurement model analysis and indicated that all variables in this study are reliable and valid. The result showed the range of loading values for all indicators is 0.470 to 0.925 . Based on Hair et al. (2012), the recommended loadings values must more than 0.708 or higher however indicators loadings values less than $0.7,0.6$, 0.5 or 0.4 still acceptable if others loadings achieved high loadings score and completed recommended values for AVE and CR. In results, all indicators in this study are reliable and valid in this study. The results shown there are fewer multicollinearity issues among variables since the values for all variables are less than 0.90 based on the measurement for Heterotrait-monotrait (HTMT.90) Conservative criteria as suggested by Gold, Malhotra and Albert (2001). The path coefficient results in this study revealed that $\mathrm{H} 4$ and $\mathrm{H} 7$ are accepted since the result indicated that privacy risk and delivery risk are significant to purchase intention by achieving recommended t-values based on Hair et al. (2012). Hair et al. (2012) further added that the recommended t-value for one-tailed hypothesis must more than 1.645. Therefore, $\mathrm{H} 4$ and $\mathrm{H} 7$ only accepted in this study.

\section{Discussion}

Based on the result of path coefficient, privacy risk and delivery risk are significant to purchase intention among online consumers in Malaysia. Meanwhile, financial risk, product performance risk, time risk, psychological risk, social risk and after-sale risk are not significant to purchase intention. This indicated that Malaysian online consumers tend to care their personal information has been misused by third parties within their permission to prevent privacy risk in online shopping activities. This can be supported by the review from Asawa and Kumar (2016). Kumar and Bajaj (2016) and Zhang et al. (2012) stated that consumers' personal information such as email address might be misused by online retailers without permission which results online consumers avoid online shopping activities. Moreover, Malaysian online consumers concerned delivery risk before intend to make purchasing in online shopping. This can justify that Malaysian online consumers concerned the delivery process result after online purchasing done. It can be supported by the review from Zhang et al. (2012) stated that online consumers prior for delivery result include product loss when doing online purchasing regarding delivery risk. Besides, this is corresponding to review from Zheng et al. (2012) and Ariff et al. (2014) declared that consumers feel fear due to the product are broken when delivered. The researchers justify that online consumers in this study does not concerned financial risk and product performance risk, as well as time risk due to they typically shops with familiar online retailers or purchase online products from familiar brand since financial risk related to monetary loss, and product performance risk related to product functionality as well as time risk related to possibility of time loss. This line with the study from Aghekyan Simonian et. al. (2012) appended normally online consumers with shops with familiar online retailers. Furthermore, the researchers justify that Malaysian online consumers tend to online purchase with online retailers that have great website design and functionality which results psychological risk does not concern by online consumers in Malaysia which supported by the finding from Tanadi et al. (2015). Moreover, Malaysian online consumers do not concern social risk when online purchasing due to positive word of mouth among social groups that supported by Zheng et al. (2012). Lastly, Malaysian online consumers do not concern after-sale risk when doing online purchasing due to well settlement performance provided by online retailers which can be supported by the review from Chen and Teng (2013).

\section{References}

Aghekyan Simonian, M., Forsythe, S., Kwon, W. S., \& Chattaraman, V. (2012). The role of product brand image and online store image on perceived risks and online purchase intentions for apparel. Journal of Retailing and Consumer Services, 19(3), 325-331. https://doi.org/10.1016/j.jretconser.2012.03.006

Ariff, M. S. M., Sylvester, M., Zakuan, N., Ismail, K., \& Ali, K. M. (2014). Consumer perceived risk, attitude and online shopping behaviour: Empirical evidence from Malaysia. Paper presented at the IOP Conference Series: Materials Science and Engineering. https://doi.org/10.1088/1757-899X/58/1/012007 
Asawa, A., \& Kumar, V. (2016). A study on perceived risk \& trust in online shopping: a comparative study among various demographic groups of Pune shoppers. Paper presented at the International Conference Strategies for Business Intelligence.

Bauer, R. A. (1960). Consumer behavior as risk taking. Paper presented at the Dynamic marketing for a changing world.

Chen, M.-Y. (2015). Do the Factors of Online Store Image Have a Parallel Relationship?. Paper presented at the Proceedings of the 2007 Academy of Marketing Science (AMS) Annual Conference. https://doi.org/10.1007/978-3-319-11806-2_76

Chen, M.-Y., \& Teng, C.-I. (2013). A comprehensive model of the effects of online store image on purchase intention in an e-commerce environment. Electronic Commerce Research, 13(1), 1-23. https://doi.org/10.1007/s10660-013-9104-5

Cox, D. F., \& Rich, S. U. (1964). Perceived risk and consumer decision-making: The case of telephone shopping. Journal of Marketing Research, 1(4), 32-39. https://doi.org/10.1177/002224376400100405

Dhanapal, S., Vashu, D., \& Subramaniam, T. (2015). Perceptions on the challenges of online purchasing: a study from "baby boomers", generation "X" and generation "Y" point of views. Contaduría y Administración, 60(S1), 107-132. https://doi.org/10.1016/j.cya.2015.08.003

Gold, A. H., Malhotra, A., \& Albert, S. H. (2001). Knowledge management: An organizational capabilities perspective. Journal of Management Information Systems, 18(1), 185-214. https://doi.org/10.1080/07421222.2001.11045669

Hair, S. M., Ringle, C. M., \& Mena, J. A. (2012). An assessment of the use of partial least squares structural equation modeling in marketing research. Journal of the Academy of Marketing Science, 40(3), 414-433. https://doi.org/10.1007/s11747-011-0261-6

Javadi, M. H. M., Dolatabadi, H. R., Nourbakhsh, M., Poursaeedi, A., \& Asadollahi, A. R. (2012). An analysis of factors affecting on online shopping behavior of consumers. International Journal of Marketing Studies, 4(5), 81-89. https://doi.org/10.5539/ijms.v4n5p81

Juniwati. (2014). Influence of perceived usefulness, ease of use, risk on attitude and intention to shop online. European Journal of Business and Management, 6(27), 218-228.

Kumar, P., \& Bajaj, R. (2016). Dimensions of perceived risk among students of high educational institutes towards online shopping in Punjab. Journal of Internet Banking and Commerce, 21(S5), 1-21.

Lissitsa, S., \& Kol, O. (2016). Generation X vs. Generation Y-A decade of online shopping. Journal of Retailing and Consumer Services, 31, 304-312. https://doi.org/10.1016/j.jretconser.2016.04.015

Lu, M. H., Zulkiffli, W. F. W., \& Hamsani, N. H. (2016). The impact of perceived risk towards customer attitude in online shopping. International Journal of Accounting, Finance and Business, 1(2), 13-21.

Morad, M., \& Raman, S. (2015). The Risk Faced by Consumers in E-Retailing. International Journal of Accounting Business and Management, 1(1), 1-8. https://doi.org/10.24924/ijabm/2015.04/v3.iss1/292.299

Pappas, N. (2016). Marketing strategies, perceived risks, and consumer trust in online buying behaviour. Journal of Retailing and Consumer Services, 29, 92-103. https://doi.org/10.1016/j.jretconser.2015.11.007

Rahman, K. M., \& Zhang, D. (2017). Globalization and Family Values: Eroding Trends. International Journal of Social and Administrative Sciences, 2(2), 63-74. https://doi.org/10.18488/journal.136.2017.22.63.74

Raza, H., Ahmed, F., Mohiuddin, Z. A., \& Osama, A. (2017). Mitigating Financial Burden of Elderly through Social Protection Schemes: Issues and Challenges for Pakistan. International Journal of Emerging Trends in Social Sciences, 1(2), 81-89. https://doi.org/10.20448/2001.12.81.89

Riaz, N., \& Riaz, S. (2018). Investment and Economic Growth: A Panel Data Analysis. Asian Development Policy Review, 6(1), 20-31. https://doi.org/10.18488/journal.107.2018.61.20.31

Rindell, A. (2013). Time in corporate images: Introducing image heritage and image-in-use. Qualitative Market Research: An International Journal, 16(2), 197-213. https://doi.org/10.1108/13522751311317594

Singh, H. S. I., Hussein, S. B. M., \& Dahlan, N. K. B. (2018). The Api-Api Constructive Trust Test: Coming Out of the Murky Into Dangerous Waters?. International Journal of Asian Social Science, 8(11), 1068-1076. https://doi.org/10.18488/journal.1.2018.811.1068.1076 
Singh, R. (2018). Perspectives on India-Bangladesh Water Dispute: The Farakka Barrage. Asian Themes in Social Sciences Research, 1(1), 14-20. https://doi.org/10.33094/journal.139.2018.11.14.20

Tanadi, T., Samadi, B., \& Gharleghi, B. (2015). The impact of perceived risks and perceived benefits to improve an online intention among Generation-Y in Malaysia. Asian Social Science, 11(26), 226-237. https://doi.org/10.5539/ass.v11n26p226

Thakur, R., \& Srivastava, M. (2015). A study on the impact of consumer risk perception and innovativeness on online shopping in India. International Journal of Retail \& Distribution Management, 43(2), 148-166. https://doi.org/10.1108/IJRDM-06-2013-0128

Zhang, L., Tan, W., Xu, Y., \& Tan, G. (2012). Dimensions of consumers' perceived risk and their influences on online consumers' purchasing behavior. Communications in Information Science and Management Engineering, 2(7), 8-14. https://doi.org/10.1007/978-3-642-24823-8_1

Zheng, L., Favier, M., Huang, P., \& Coat, F. (2012). Chinese consumer perceived risk and risk relievers in e-shopping for clothing. Journal of Electronic Commerce Research, 13(3), 255. 